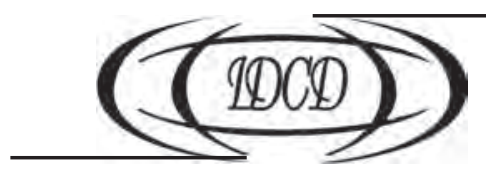

doi: $10.15407 /$ dse2016.03.0183

УДК 336.14: 336.27

JEL Classification: H72, H74

\title{
Н.М. ДЕЕВА
}

д-р екон. наук, проф., гол. наук. співроб.

Інститут демографії та соціальних

досліджень ім. М.В. Птухи НАН України

01032, м. Київ, бул. Т. Шевченка, 60

E-mail:dn_n@ukr.net

\section{СОЦІАЛЬНА ФУНКЦІЯ ДЕРЖАВИ: ПРАКТИКА I ЗАВДАННЯ БЮДЖЕТНОГО ЗАБЕЗПЕЧЕННЯ}

\begin{abstract}
Досліджено особливості реалізації соціальної функції державою в контексті їі соціалізаційних можливостей. Особливу увагу приділено дослідженню тиску на бюджет усе більших видатків на обслуговування зовнішнього боргу $і$ зменшенню у зв'язку з цим соціалізаційного потенціалу країни. Встановлено характер змін у структурі соціальних видатків під впливом боргового навантаження. Оцінено дії владних інститутів на предмет підтримання збалансованості суспільства за доходами і майновим станом. Надано характеристику динаміці видатків на соціальний захист і соціальне забезпечення населення, як індикатору зростання масштабів бідності. Виявлено деструкції в ефективності використання бюджетних коштів, які витрачаються на соціальний захист населення. Встановлено причини деформованого сприйняття соціальної функції держави в ринковому середовищі за умови здавалося б очевидних орієнтирів в їі задіянні на потреби соціалізації. Обгрунтовано концепт країни як великої відкритої соціальної системи і наслідки звуження ї̈ масштабів до систем нижчого рівня. Узагальнено умови досягнення соціальних цілей державою через забезпечення виконання законів всіма суб'єктами економіки. Пропонується впровадити в практику бюджетування складання соціального бюджету держави та їі регіонів у розрізі відповідних територіальних одиниць.
\end{abstract}

Ключові слова: соціальна держава, функції, соціалізація, потенціал, реалізація, бюджетне фінансування, деструкції, перспективи.

\section{Н.Н. Деева}

д-р екон. наук, проф., глав. науч. сотруд.

Институт демографии и социальных

исследований им. М.В. Птухи НАН Украины

01032, Украина, г. Киев, бул. Т. Шевченко, 60

E-mail: dn_n@ukr.net

\section{СОЦИАЛЬНАЯ ФУНКЦИЯ ГОСУДАРСТВА: ПРАКТИКА И ЗАДАЧИ БЮДЖЕТНОГО ОБЕСПЕЧЕНИЯ}

Исследованы особенности реализации социальной функции государством в контексте ее социализационных возможностей. Особое внимание уделено исследованию давления на бюджет растущих расходов на обслуживание внешнего долга и уменьшению, в связи с этим, социализационного потенциала страны. Установлен характер изменений в структуре социальных расходов под влиянием долговой нагрузки.

(с) ДЄЄВА Н.М., 2016 
Оиенены действия властных институтов на предмет поддержания сбалансированности общества по доходам и имущественному положению. Охарактеризованы динамика расходов на социальную защиту и социальное обеспечение населения как индикаторы роста масштабов бедности. Выявлено деструкции в эффективности использования бюджетных средств, которые тратятся на социальную защиту населения. Установлены причины деформированного восприятия социальной функции государства в рыночной среде при, казалось бы, очевидных ориентирах в ее задействовании на нужды социализации. Обоснованно концепт страны как большой открытой социальной системы и последствия сужения ее масштаба к системам низкого уровня. Обобщены условия достижения социальных целей государством путем обеспечения выполнения законов всеми субъектами экономики. Предлагается внедрить в практику бюджетирования составление социального бюджета государства и его регионов в разрезе соответствующих территориальных единиц.

Ключевые слова: социальное государство, функции, социализация, потенциал, реализация, бюджетное финансирование, деструкции, перспективы.

\section{N.M. Dieieva}

Dr. Sc. (Economics), Prof., Leading research fellow

Ptoukha Institute for Demography and Social Studies

of the National Academy of Sciences of Ukraine

01032, Ukraine, Kyiv, blvd. Taras Shevchenko, 60

E-mail:dn_n@ukr.net

\section{SOCIAL FUNCTION OF THE STATE: PRACTICE AND OBJECTIVES OF BUDGET PROVIDING}

In the article the features of realization of the state social function in the context of the socialization opportunities are researched. Particular attention is paid to analyzing the growing pressure on budget spending on external debt and, in connection with this, reduction of social development potential. The character of changes in the structure of social spending under the influence of the debt burden is defined. The actions of government institutions in terms of maintaining social balance of income and property status is reviewed. The characteristic of the dynamics of social protection and social security of population growth as an indicator of poverty is characterized. Degradation in efficiency of budget funds spent on social protection is revealed. The causes of deformed perception of the social functions of the state in a market environment provided a seemingly obvious reference in its mobilization to the needs of socialization. The concept of country as a large open social system and the effects of narrowing of its scope to lower levels are grounded. Conditions of maintenance of social goals by the state through the enforcement of laws by all economic actors are generalized. Implementation of the practice of social budgeting of the state budget and its regions in the context of the relevant units is proposed.

Keywords: social state functions, socialization, potential, implementation, financing, destructions, prospects.

Постановка проблеми. Україна відповідно до Конституції є соціальною державою [1]. Реалізація основних вимог цього суспільного інституту передбачає відповідальність суспільства за умови існування кожного громадянина і водночас кожен громадянин має бути відповідальним за формування власного добробуту. У цьому контексті в Основному законі й інших нормативно-правових актах затверджені базові положення, що фіксують зобов'язання держави в соціальній сфері, в інтересах добробуту громадян загалом і соціальних груп, зокрема [2-4]. Мова йде не тільки й не скільки про створення нової системи соціальних гарантій, а насамперед про задіяння соціальних факторів забезпечення економічного зростання в системі мотивації соціально відповідальної поведінки суб'єктів господарювання і найманих працівників. Розбудова соціальної держави з ринковою економікою відносно нового типу для України з відходом від патерналістської держави ставить проблему соціалізації економіки на принципово іншому рівні. При цьому вибір шляхів і методів соціалізації, тобто досягнення прийнятного результату взаємодії економічного і соціального на- 
прямів, не є вільним. Незалежно від того, на якій інструментальній базі будується соціальна держава, первинну роль відіграє виробництво в сукупності з розподілом, обміном та споживанням. Природно, що суспільство може ставити до вирішення лише ті завдання з соціальним підтекстом, щодо яких назріли реальні передумови і наявні відповідні ресурси. Можливості суспільства щодо соціалізації через сукупну здатність суб'єктів економіки пов'язуються з потенціалом ііі здійснення. Саме потенціал соціалізації відображає не стільки статику можливостей держави, скільки динаміку процесу формування і розвитку здатності до продукування основ життя, які б повною мірою задовольняли населення [5].

Але реальне здійснення соціально спрямованих дій у нашій державі не завжди кореспондувалося з наявним потенціалом соціалізації, рівень змін і залучення якого до підтримання й розвитку основ забезпечення добробуту є надійним фундаментом прогресивної соціальної динаміки суспільства.

Аналіз останніх досліджень і публікацій. Теоретичну змістовність процесів насичення економічної діяльності соціальними аспектами репрезентують праці найвідоміших представників західної наукової думки і, зокрема, Г. Бортіса (G. Bortis), Л. Гумпловича (L. Gumplowicz), Л. Ерхарда (L. Erhard), Дж. Кейнса (J. Keynes), Р. Ліфмана (R. Lifman), K. Маркса (K. Marx), T. Маршалла (T. Marshall), А. Мюллера-Армака (A. Myuller-Armak), В. Ойкена (V. Oyken), В. Рьопке (V. Ropke), А. СенСімона (А. Saint-Simon), П. Сорокіна (P. Sorokin), Дж. Стіглера (J. Stigler), Р. Тітмаса (G. Titmas), Ф. Фабриціуса (F. Fabricius), Л. фон Штейна (L. von Stein), Й. Шумпетера (J. Schumpeter) та багатьох інших.

Виходячи з того, що соціальні питання суспільного розвитку є предметом розгляду філософських, економічних, політичних та соціальних наук, період незалежного господарювання характеризується сплеском національної наукової думки з опрацюванням теоретико-методологічних питань соціалізації економіки, забезпечення соціальної орієнтації в ринковій економіці, обгрунтування соціальної політики, механізму надання суспільних послуг тощо. Особливо виділяються в цьому контексті наукові пошуки О. Василика (O. Vasylyk), О. Власюка (O. Vlasyuk), В. Гейця (V. Geyets), А. Даниленко (A. Danilenko), В. Дем'янишина (V. Demyanyshyn), В. Опаріна (V. Oparin), К. Павлюк (K. Pawluk), С. Мочерного (S. Mocherny), Л. Тимошенко (L. Tymoshenko) та ін.

У зв'язку з нагальною потребою посилення фінансової забезпеченості державного і місцевих бюджетів та їх прямого впливу на розв'язання складних питань щодо зменшення нерівності і рівня бідності населення в Україні широкий спектр цих питань висвітлений в останні роки провідними науковцями Інституту демографії та соціальних досліджень імені М.В. Птухи НАН України, а саме Е. Лібановою (Е. Libanova), О. Макаровою (О. Makarova), Л. Лісогор (L. Lisogor), В. Новіковим (V. Novikov), T. Заяць (T. Zayats), В. Саріогло (V. Sarioglo), О. Цимбалом (O. Tsymbal) та ін. [6-8]. Проте складність і суперечність соціальних процесів, що відбуваються в країні, настільки значні, що ряд питань оцінки збалансованості соціальних потреб потенціалу соціалізації виокремлюються в якості недостатньо вивчених і розроблених через, насамперед, надзвичайно високу динамічність як в економічному, так і соціальному житті.

Постановка завдання. У зв'язку із зазначеним вище метою статті є ретроспективна оцінка тиску зобов'язань держави на обсяги соціальних видатків бюджету і виявлення деструкцій в їх використанні та узагальнення умов досягнення соціальних цілей державою через подолання стереотипу бюджетної і фінансової політики 
взагалі, пріоритетом якої до останнього часу залишаються витрати на підтримку життєдіяльності населення, а не нарощування можливостей формування державою потенцій до самозабезпечення добробуту.

Виклад основного матеріалу дослідження. Основним суб’єктом узгодження уподобань різнополярного характеру бізнесу, населення і держави щодо розподілу створеного продукту, як правило, є держава, хоча і не без тиску і не без схвалення з боку населення [3, 4]. У прагненні виконати власне соціальне призначення держава, втручаючись у соціально-економічні процеси, має оптимально поєднувати у своїх діях якості, перш за все, суб'єкта й інституту забезпечення соціального партнерства та соціальних гарантій суспільства. Перехід від декларування соціальної конверсії економіки до реальної зміни пріоритетів соціально-економічного розвитку може забезпечити лише певне матеріальне підгрунтя. Від того, наскільки достатніми будуть його обсяги та ефективність використання потужностей їх продукування, наскільки великий обсяг соціальної відповідальності будуть готові взяти на себе суб'єкти економіки, залежить результативність, швидкість і тривалість соціальнотрансформаційних процесів на національних теренах у напрямі формування основ добробуту населення. У фаховій літературі це положення стало аксіоматичним і його практично не заперечують.

Але специфічність української ситуації щодо формування й розвитку потенціалу соціалізації полягає в тому, що ініціювання соціально-ринкового трансформування економіки відбулося зверху і, тим самим, було порушено баланс між соціальними і економічними складниками генерування соціально-економічного розвитку. Одним із переконливих проявів розбалансованості економічних можливостей і рівня задоволення соціальних потреб є зміна обсягів державного та гарантованого державою боргу в 2000-2015 pр., тобто за період проведення двох бюджетних реформ і прийняття першого Бюджетного кодексу у 2001 р. [9]. та другого - у 2010 р. [10]. Наведені на рис. 1 характерні для цих змін показники свідчать не лише про різке зростання державного та гарантованого державою боргу, починаючи з 2007 року, а й перевищення ним з 2009 р. взагалі доходів Зведеного бюджету України (надалі ЗБУ).

За нашими розрахунками, в 2015 р. обсяг державного та гарантованого державою боргу перевищив доходи ЗБУ в 2,4 рази. Щодо зовнішнього державного боргу країни, то він був більшим за доходи ЗБУ на 174 млрд грн.

Однак справа не лише в кількісних змінах обсягів державного й гарантованого державою боргу та зовнішнього державного боргу країни. Щороку зростає обсяг, що витрачається на обслуговування боргу держави. Тільки у 2015 р. видатки державного бюджету на обслуговування боргу збільшилися порівняно з 2014 р. на 36,8 млрд грн і склали на початок 2016 р. понад 86,2 млрд грн.

Тиск на бюджет видатків на обслуговування боргу, що постійно зростають, у свою чергу зменшує соціалізаційний потенціал країни. Згідно з проведеними розрахунками, обсяг видатків державного бюджету на обслуговування боргу держави на 20 відсотків перевищив видатки на охорону здоров’я (рис. 2 ).

Покладання уряду України на зовнішнє фінансування дефіциту бюджету можна було б сприймати позитивно, якби залучені кошти використовувалися на фінансування інвестиційних проектів, базових галузей економіки з отриманням у майбутньому прибутків для покриття боргу і відсотків за ним. Але зовнішні позики до останнього часу використовуються для фінансування поточних витрат.

Водночас, ставлячи під сумнів доцільність політики зовнішніх запозичень, все-таки в умовах тієї економічної політики, яку проводить Україна, вона постійно 


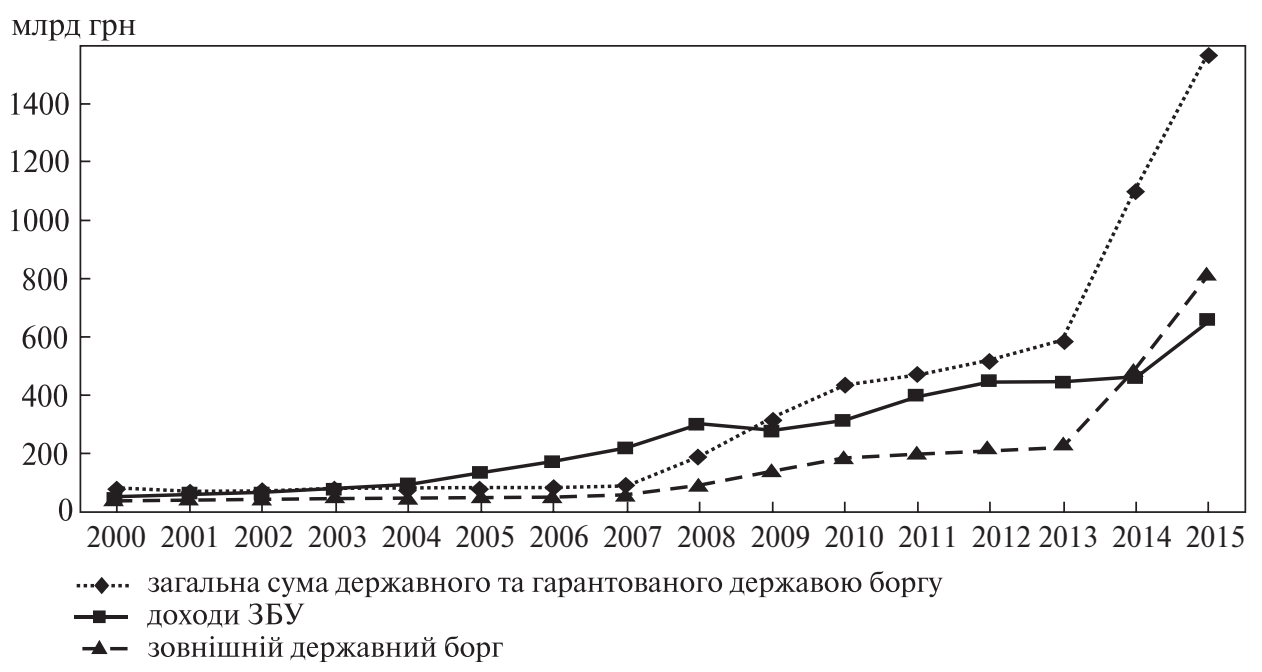

Рис. 1. Динаміка змін загальної суми державного та гарантованого державою боргу, доходів ЗБУ, зовнішнього державного боргу у 2000-2015 pp.

Джерело: складено за даними Міністерства фінансів України.

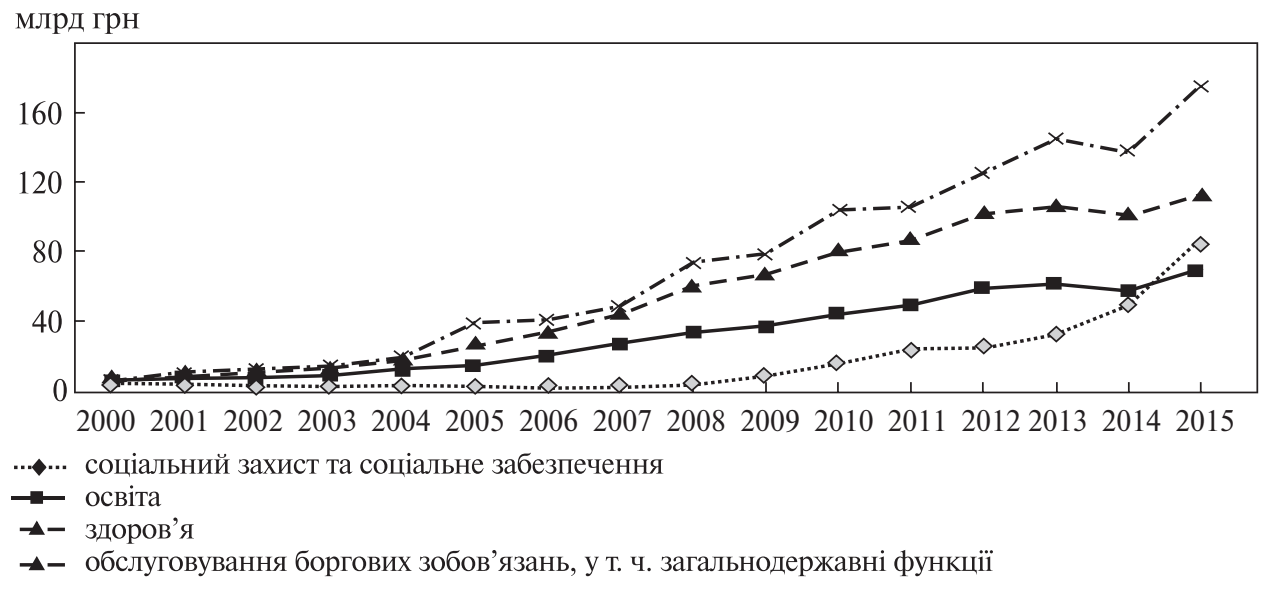

Рис. 2. Динаміка змін обсягів обслуговування боргових зобов'язань держави у порівнянні із видатками на охорону здоров'я, освіту, соціальний захист та соціальне забезпечення у 2001-2015 pp. Джерело: складено за даними Міністерства фінансів України.

й вимушено буде орієнтуватися на позичковий капітал і зменшення внутрішнього споживання.

В Аналітичній доповіді Національного інституту стратегічних досліджень до Щорічного послання Президента України «Про внутрішнє та зовнішнє становище в Україні в 2016 році» «надмірне боргове навантаження» віднесено до низки найскладніших «викликів та загроз фінансовій системі» держави. В ній констатується, що «...відносно ВВП державний та гарантований державою борг у 2015 році становив 79,4 \% (69,4 \% ВВП у 2014 році), що перевищує граничну межу боргового навантаження у 60 \% ВВП, передбачену Бюджетним кодексом України» [11, с. 64]. 
Це проблема, яку не відокремити від питань взаємодії суспільства й людини, суспільного розвитку, формування ефективної економічної бази держави й доведення рівня добробуту до стандартів цивілізаційного виміру. У прагненні залучити кредити для покриття боргових зобов'язань владні інститути своїми діями деформували соціально-економічні відносини і звели нанівець міру збалансованості суспільства за доходами і майновим станом. Постає питання: чому країна, маючи порівняно розвинену техніко-технологічну базу, наукові й інженерні кадри, трудові, природно-сировинні й матеріально-енергетичні ресурси, стала неспроможною протягом тривалого періоду вирішити поточні проблеми добробуту населення навіть вітального рівня, не говорячи вже про стратегічні завдання? Нагромаджені суперечності в соціальній політиці стали причиною значного розшарування суспільства.

За висновками директора Інституту демографії та соціальних досліджень імені М.В. Птухи НАН України академіка НАН України Е.М. Лібанової, «...наслідком надмірної диференціації доходів населення є консервування масштабної бідності та істотне (у 3-5 разів) перевищення суб'єктивними оцінками іiі рівня, визначеного за об’єктивними критеріями... Виправити ситуацію може тільки трансформація політики доходів, зокрема її спрямування на зниження нерівності, значне підвищення доходів працюючих, дієву підтримку бідних верств» [12].

За результатами розрахунків рівня бідності населення, які виконують фахівці ІДСД ім. М.В. Птухи НАН України на підставі даних обстеження умов життя домогосподарств Державною службою статистики України, за межею відносної бідності за витратами у 2015 р., яка становила 1560 грн, перебувало 22,9 \% населення. Найбільш негативними тенденціями бідності населення в Україні серед різних типів домогосподарств є наявність у них дітей. У 2015 році рівень відносної та абсолютної бідності загалом по домогосподарствах з дітьми перевищував в 1,8 та 2,5 рази відповідні показники по сукупності домогосподарств без дітей. Найвищі ризики бідності за відносним критерієм мають домогосподарства з трьома дітьми - 48,9 \% (в 2013 році - 59,8, у 2014 р - 46,6); з двома дітьми - 38,6 (в 2013 році - 38,8 у 2014 р - 41,9); з дітьми до трьох років - 34,0 (в 2013 році - 32,8, у 2014 р - 30,5).

Парадоксальність ситуації полягає у тому, що перманентна тенденція високого рівня бідності населення, особливо тих домогосподарств, що утримують дітей, відбувається в умовах щорічного зростання обсягів видатків на соціальний захист і соціальне забезпечення населення в абсолютному і відносному вимірі у видатках ЗБУ, які вже перевищують видатки на освіту і охорону здоров'я, спрямовані на формування людського капіталу як основи самозабезпечення потреб (рис. 3).

Питома вага видатків на соціальний захист та соціальне забезпечення населення зросла за 1999-2015 pр. із 16,1 до 25,9 \% і з 2008 р. практично складає вже понад чверть видатків ЗБУ. Виокремлені і підтверджені трендом на рис. 3 реалії зростання питомої ваги видатків на соціальний захист відбуваються не за рахунок адекватного зростання доходів бюджету і підвищення соціальних стандартів і гарантій, а через утримання на одному рівні, а подекуди й зменшення часток тих видатків ЗБУ, що витрачаються для надання послуг соціальної інфраструктури всім верствам населення, насамперед по галузях «освіта» та «охорона здоров’я». Так, питома вага видатків на охорону здоров'я за 2002-2015 роки зменшилася із 12,5 до 10,4 \% , а на освіту - із 20,3 до 16,8 \%. Видатки на соціальний захист та соціальне забезпечення населення за 2014-2015 роки були більшими від видатків на освіту в середньому у півтора рази, а на охорону здоров’я - більш ніж у 2,4-2,5 разів відповідно. 


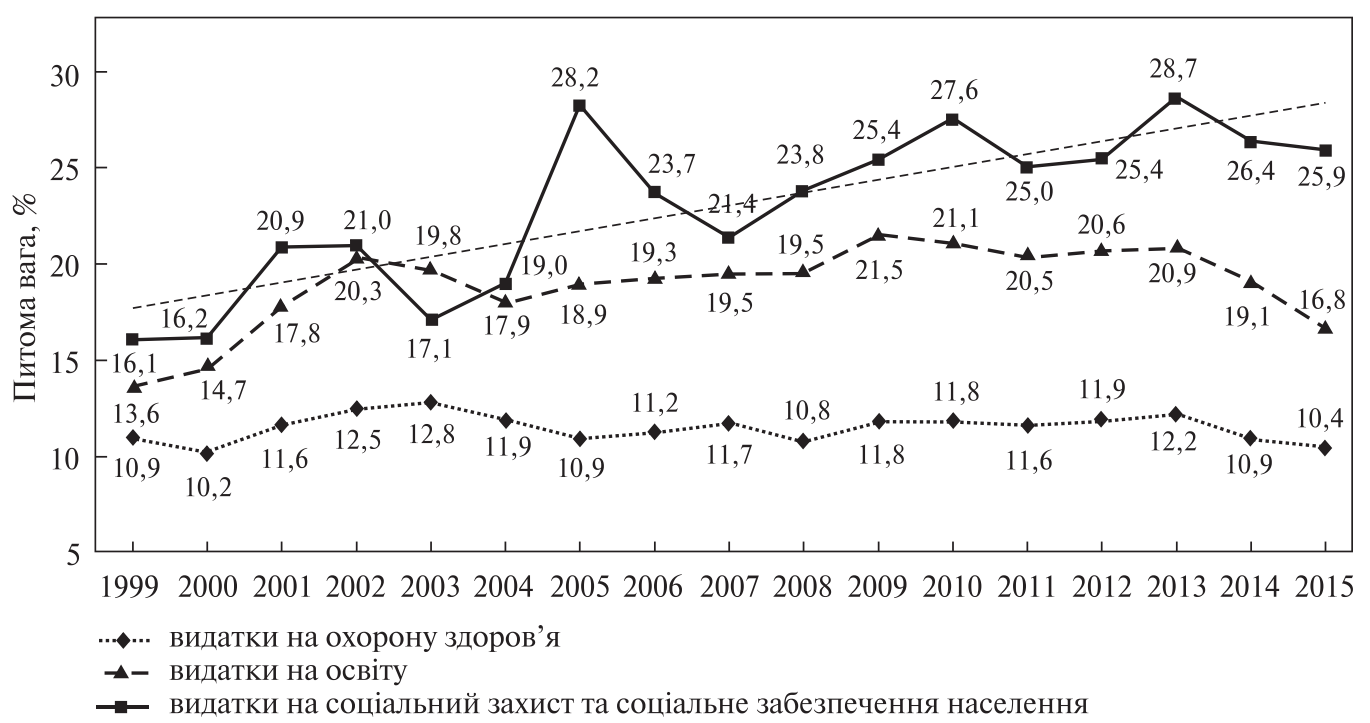

Рис. 3. Зміна питомої ваги соціальних видатків у загальному обсязі видатків ЗБУ в 1999-2015 pp.

Джерело: складено і розраховано автором за даними статистичних збірників Міністерства фінансів України («Бюджет України») за відповідні роки.

Водночас слід враховувати й іншу обставину: реконструкція соціальних видатків і нарощування витрат на соціальний захист та соціальне забезпечення населення не відтворюють позитивних змін у добробутних позиціях населення.

За висновками відомого фахівця з соціальної політики Л.М. Черенько, «... система державної соціальної підтримки як важіль прямого впливу на бідність виявилася абсолютно непристосованою до нових умов і не здатна відповісти на нові виклики» [13].

Підтвердженням неефективного використання бюджетних коштів, які витрачаються на соціальний захист населення, є офіційні висновки, закладені в «Стратегії подолання бідності», про те, що «Програмами соціальної підтримки охоплено 58,3 відсотка бідного населення, при цьому лише 41 \% коштів соціальних програм (без урахування житлових субсидій) використано на задоволення потреб такого населення. Водночас серед отримувачів усіх видів соціальної підтримки лише 25 \% належало до бідного населення» [14].

Отже, формальне посилення соціальної функції держави за рахунок видатків ЗБУ на соціальний захист та соціальне забезпечення в принципі є асоціальним явищем, оскільки воно не сприяє зменшенню рівня й масштабів бідності населення, а навпаки, сприяє його зростанню й розширює коло маргіналів. Більш того, сповідування подібного принципу забезпечення соціальності у суспільстві призвело до непомірного перевантаження соціальної функції держави концентрацією на рівні центральних органів влади всіх механізмів і можливостей для забезпечення добробуту населення 3 практичним відстороненням останнього від вирішення проблем позитивної динаміки власного життя за рахунок власної праці.

Відомий німецький теоретик медіа і комунікацій Норберт Больц з цього приводу зазначив, що «опікуюча соціальна держава оперує трьома помилками: вона судить про нерівність через дискримінацію, дискримінація виводиться з соціальних 
причин, а соціальні причини призводять до патерналістських заходів. Намагаючись допомогти жертвам соціальною допомогою, держава загального добробуту сприяє тому, що їх число тільки зростає ... Таким чином, політика перерозподілу не бореться з бідністю, а знижує витрати на бідність» [15]. Постає методологічне питання щодо причин деформованого сприйняття соціальної функції держави за умови здавалося б очевидних орієнтирів в ii задіянні на потреби соціалізації. Це проблема досить принципового значення. Якщо абстрагуватися і не враховувати соціально-економічний устрій, то будь-яка країна внаслідок свого соціального призначення $є$ великою відкритою соціальною системою. Саме соціальною, а не соціально-економічною, як стверджують деякі фахівці $[16,17]$. За всіма ознаками вона є складною і містить у собі безліч інших підсистем, відповідно до виконуваних функцій.

Конструюючим центром і невід’ємною частиною соціальної системи є людина. Задоволення потреб членів суспільства є метою діяльності подібної системи. Щодо систем нижчого рівня, то, зокрема, для економічної системи людина ототожнюється з матеріально-речовими або суто економічними наслідками іншого характеру [18]. Виходить, що природні межі соціальної системи через об'єктивні обставини вже тривалий час штучно звужені до системи нижчого рівня, яку називають соціальноекономічною. На мій погляд, це формує усвідомлення у владному середовищі і наголос на частковості забезпечення соціального призначення держави, незважаючи на конституційне проголошення України соціальною державою.

Висновок та перспективи подальших досліджень. Безумовно, втілювати будь-яку теорію в життя набагато складніше від ії̈ створення та тлумачення. Фактичний перехід у систему координат соціальної держави, в якій повною мірою мали б бути задіяні такі основоположні принципи розвитку, як цілеспрямованість, варіативність, оптимальність, динамічність, є питанням часу. Але не тільки. Якби не тлумачили соціалізацію економіки і з яких би позицій іiї не розглядали, основним суб'єктом ії реалізації виступає держава, а влада в державі стає ефективною тоді, коли вміє визначати норми і правила здійснення конкретних функцій, відповідно до умов досягнення соціальних цілей держави, що дозволяють зберегти часову перевагу або послабити деякі з них за одночасного посилення інших. Успіхів же досягає та влада, яка не тільки формує законодавче середовище виконання соціального призначення держави, а насамперед завжди виконує їх сама і тим самим уже створює умови для забезпечення виконання законів усіма суб'єктами економіки. На жаль, українські традиції виконання владних повноважень допускають повільність і навіть довільність виконання Конституції України і законодавчих актів. Стихійне запровадження вибірковості виконання законодавчих актів і соціальних норм з часом формально ніби «унормувалось» $\mathrm{i}$, як наслідок, «розшарпалась» сама сутність термінів, «законність» і «відповідальність» суб’єктів економіки, що врешті-решт призвело до викривлення всіх напрямів формування і проведення державної та регіональної соціальної політики.

У вже згаданій Аналітичній доповіді Національного інституту стратегічних досліджень до Щорічного послання Президента України «Про внутрішнє та зовнішнє становище в Україні в 2016 році» наголошується, що «криза не лише карає за помилки минулого, але й дарує можливість перейти до нової якості держави в майбутньому. Для цього необхідно сформувати чітку систему пріоритетів національного розвитку, визначити свої цілі, здійснити інвентаризацію ресурсів і резервів, ідентифікувати основні ризики та загрози» [11]. У цьому контексті пропонуємо:

Перше. Створити систему формування й реалізації соціальної політики не на підгрунті підпорядкованості, а на засадах узгодженості інтересів і дій. 
Друге. Впровадити в практику бюджетування складання соціального бюджету держави та іiі регіонів у розрізі відповідних територіальних одиниць, який забезпечить:

- системний підхід до формування і виконання соціальних заходів та їх взаємозв'язок між економічними показниками, демографічним прогнозом і соціальним сектором;

- своєчасне і в повному обсязі враховування змін бюджетного, податкового і соціального законодавства та відповідних нормативних актів при щорічному та перспективному плануванні обсягу соціальних послуг і специфіки системи соціального забезпечення окремих регіонів та їх територій;

- уникнення формалізму щодо впровадження програмно-цільового методу формування місцевих бюджетів із одночасним його впровадженням у Державному бюджеті;

- об’єднання фінансових ресурсів усіх інституцій планування і використання бюджету незалежно від рівня їх формування, що мінімізує ризики в ході планування і виконання соціальної політики держави та забезпечить ефективність використання бюджетних коштів.

\section{ЛІТЕРАТУРА}

1. Конституція України від 28 червня 1996 року № 254к/96-ВР. Верховна Рада України [Електронний ресурс]. - Режим доступу: http://zakon4.rada.gov.ua/laws/show/254\%D0\%BA/96-\%D0\%B2$\% \mathrm{D} 1 \% 80$

2. Декларація Верховної Ради УРСР від 16.07.1990 р. № 55-ХІІ «Про державний суверенітет України» [Електронний ресурс]. - Режим доступу: http://zakon2.rada.gov.ua/laws/show/55-12

3. Основні напрями соціальної політики на 1997-2000рр.: Затверджені Указом Президента України від 18 жовтня 1997 р. № 1166/97 // Урядовий кур’єр. - 1997. - № 202-203.

4. Основні напрями соціальної політики на період до 2004 року: Схвалено Указом Президента України від 24 травня 2000 року № 717/2000 // Офіційний вісник України. - 2000. - № 21. C. $11-32$.

5. Дєєва Н.М. Потенціал соціалізації і його регулювання в економіці: теорія, методологія, перспективи : Монографія. - Дніпропетровськ : АРТ_ПРЕСС, 2006.

6. Макарова О.В. Соціальна політика в Україні: Монографія / О.В. Макарова; Ін-т демографії та соціальних досліджень ім. М.В. Птухи НАН України. - К., 2015. - 244 с.

7. Людський розвиток в Україні: історичний вимір трансформації державної соціальної політики (колективна монографія) / за ред. Е.М. Лібанової; Ін-т демографії та соціальних досліджень ім. М.В. Птухи НАН України. - К., 2014. - 380 с.

8. Людський розвиток в Україні: соціальні та демографічні чинники модернізації національної економіки : колективна монографія / за ред. Е.М. Лібанової. - К. : Ін-т демографії та соціальних досліджень ім. М.В. Птухи НАН України, 2012. - 320 с.

9. Бюджетний кодекс України від 21.06.2001 № 2542-III. Верховна Рада України [Електронний ресурс]. - Режим доступу: http://zakon0.rada. gov.ua /laws/show/2542-14

10. Бюджетний кодекс України від 08.07.2010 № 2456-VI. Верховна Рада України [Електронний ресурс]. - Режим доступу: http://zakon0. rada.gov.ua /laws/show/2456-17

11. Аналітична доповідь до Щорічного Послання Президента України до Верховної Ради України «Про внутрішне та зовнішне становище України в 2016 році». - К. : НІСД, 2016. - 684 с.

12. Лібанова Е. Україна: глибина нерівності / Е. Лібанова // Дзеркало тижня. Україна. - № 35. 1 жовтня 2016. [Електронний ресурс]. - Режим доступу: http://gazeta.dt.ua/internal/ukrayinaglibina-nerivnosti

13. Черенько Л.М. Нові форми бідності в Україні: основні прояви та оцінка масштабів явища / Л.М. Черенько // Демографія та соціальна економіка. - 2015. - 1(23). - С. 11-21. - doi: 10. $15407 /$ dse2015.01.011 
14. Про схвалення Стратегії подолання бідності : Розпорядження Кабінету Міністрів України від 16 березня 2016 p. № 161-p [Електронний ресурс]. - Режим доступу: http://www.kmu.gov.ua/control/uk / cardnpd?docid $=248898080$

15. Больи Н. Размышление о неравенстве. Анти-Руссо / Н. Больц; Пер. с нем. - М. : ИД Высшей школы экономики, 2014. - 272 с.

16. Моделювання соціально-економічного розвитку територій : наук.-метод. розробка / С.М. Ромашко, І.З. Саврас, Р.Г. Селівестов, Р.В. Юринець. - К. : НАДУ, 2013. - 44 с.

17. Голованенко М. Діагностування типу динаміки соціально-економічних систем з використанням топологічних тестів (на прикладі країн ЄС) / М. Голованенко // Вісник Київського національного університету імені Тараса Шевченка: Економіка. - 2013. - № 10 (151). - С. 58-61.

18. Інформаційне забезпечення державного та регіонального соціального управління: Монографія / О.Г. Осауленко, О.Ф. Новікова, Н.С. Власенко та ін.; НАН України, Ін-т економіки промисловості; Держкомстат України. - Київ; Донецьк : 2004. - С. 15.

\section{REFERENCES}

1. Konstytutsiia Ukrainy vid 28 chervnia 1996 roku № 254k/96 [The Constitution of Ukraine of 28 June, 1996 №254k/96]. (1996, 28 July). Verkhovna Rada Ukrainy. zakon.rada.gov.ua. Retrieved from http:// zakon4.rada.gov.ua/laws/show/254\%D0\%BA/96-\%D0\%B2\%D1\%80 [in Ukrainian].

2. Deklaratsiia Verkhovnoi Rady URSR vid 16.07.1990 r. № 55-XII «Pro derzhavnyi suverenitet Ukrainy» [Declaration of Supreme Council of USSR «On the State Sovereignty of Ukraine» of 16.07.1990 № 55-XII]. zakon.rada.gov.ua. Retrieved from http://zakon2.rada.gov.ua/laws/show/55-12 r [in Ukrainian].

3. Osnovni napriamy sotsialnoi polityky na 1997-2000 rr.: Zatverdzheni Ukazom Prezydenta Ukrainy vid 18 zhovtnia 1997 r. № 1166/97 [The main directions of social policy for 1997-2000, approved by President of 18 October 1997 № 1166/97 ]. (1997). Uriadovyi kur'er - Governmental Courier, 202-203 [in Ukrainian].

4. Osnovni napriamy sotsialnoi polityky na period do 2004 roku: Skhvaleno Ukazom Prezydenta Ukrainy vid 24 travnia 2000 roku № 717/2000 [The main directions of social policy for the period until 2004, approved by the Decree of the President of Ukraine of 24 May 2000 717/2000]. (2000). Ofitsiinyi visnyk Ukrainy - Official Bulletin of Ukraine, 21, 11-32 [in Ukrainian].

5. Dieieva, N.M. (2006). Potentsial sotsializatsii i yoho rehuliuvannia v ekonomitsi: teoriia, metodolohiia, perspektyvy [Potential socialization and its regulation in the economy: the theory, methodology, prospects] Dnypropetrovs'k: ART_PRESS [in Ukrainian].

6. Makarova, O.V. (2015). Sotsialna polityka v Ukraini [Social policy in Ukraine]. K.: In-t demohrafiyi ta sotsial'nykh doslidzhen' im. M.V. Ptukhy NAN Ukrayiny [in Ukrainian].

7. Liudskyi rozvytok v Ukraini: istorychnyi vymir transformatsii derzhavnoi sotsialnoi polityky [Human development in Ukraine: the historical dimension of the transformation of government social policy]. (2014). K.: In-t demohrafiyi ta sotsial'nykh doslidzhen' im. M.V. Ptukhy NAN Ukrayiny [in Ukrainian].

8. Libanova, E.M. (Ed). (2012). Liudskyi rozvytok v Ukraini: sotsialni ta demohrafichni chynnyky modernizatsii natsionalnoi ekonomiky [Human Development in Ukraine: social and demographic factors modernization of the national economy]. K.: In-t demohrafiyi ta sotsial'nykh doslidzhen' im. M.V. Ptukhy NAN Ukrayiny [in Ukrainian].

9. Biudzhetnyi kodeks Ukrainy vid 21.06.2001 № 2542-III [Budget Code of Ukraine from 21.06.2001 number 2542-III]. (2001). zakon.rada.gov.ua. Retrieved from http://zakon0.rada. gov.ua /laws/ show/2542-14 [in Ukrainian].

10. Biudzhetnyi kodeks Ukrainy vid 08.07.2010 № 2456-VI [Budget Code of Ukraine from 08.07.2010 №2456-VI]. zakon.rada.gov.ua. Retrieved from http://zakon0.rada.gov.ua/laws/show/2456-17 [in Ukrainian].

11. Analitychna dopovid do Shchorichnoho Poslannia Prezydenta Ukrainy do Verkhovnoi Rady Ukrainy «Pro vnutrishnie ta zovnishnie stanovyshche Ukrainy v 2016 rotsi» [The analytical report to the Annual Message of the President of Ukraine to the Verkhovna Rada of Ukraine «On the internal and external situation of Ukraine in 2016»] (2016). K.: NISD [in Ukrainian]. 
12. Libanova, E. (2016). Ukraina: hlybyna nerivnosti [Ukraine: depth of inequality] Dzerkalo tyzhnia - Mirror Weekly, 35. Retrieved from http://gazeta.dt.ua/internal/ukrayina-glibina-nerivnosti [in Ukrainian].

13. Cherenko, L.M. (2015). Novi formy bidnosti v Ukraini: osnovni proiavy ta otsinka masshtabiv yavyshcha [New forms of poverty in Ukraine: The main displays and rating scale phenomena] Demohrafiia ta sotsialna ekonomika - Demography and social economy, 1(23), 11-21 doi: 10.15407/dse2015.01.011 [in Ukrainian].

14. Pro skhvalennia Stratehii podolannia bidnosti: Rozporiadzhennia Kabinetu Ministriv Ukrainy vid 16 bereznia 2016 r. № 161-r. [On approval of the strategy are: Cabinet of Ministers of Ukraine dated March 16, 2016 p. Number 161-p.]. (2016). kmu.gov.ua. Retrieved from http://www.kmu.gov.ua/control/uk/ cardnpd?docid $=248898080$ [in Ukrainian].

15. Bolts, N. (2014). Razmyshlenye o neravenstve. Anty-Russo [Reflections on inequality]. M.: High society school of economy. [in Russian].

16. Romashko, S.M., Savras, I.Z., Selivestov, R.H. \& Yurynets, R.V. (2013). Modeliuvannia sotsialno-ekonomichnoho rozvytku terytorii [Modeling of socio-economic development of territories]. K.: NADU [in Ukrainian].

17. Holovanenko, M. (2013). Diahnostuvannia typu dynamiky sotsialno-ekonomichnykh system z vykorystanniam topolohichnykh testiv [Diagnosis type speakers socioeconomic systems using topological tests]. Visnyk Kyivskoho natsionalnoho universytetu imeni Tarasa Shevchenka: Ekonomika - Bulletin of Kyiv National Taras Shevchenko University: Economics, 10(151), 58-61 [in Ukrainian].

18. Osaulenko, O.H., Novikova, O.F. \& Vlasenko, N.S. (2004). Informatsiine zabezpechennia derzhavnoho ta rehionalnoho sotsialnoho upravlinnia [Information support state and regional social control]. Kyiv; Donetsk, NAS of Ukraine. Institute of Industrial Economics; State Statistics Committee of Ukraine [in Ukrainian].

Стаття надійшла до редакції журналу 19.10.2016. 